\title{
CALL FOR PROPOSALS
}

\author{
57 th Annual Meeting of the African \\ $\Longrightarrow$ Studies \\ Association \\ Rethinking Violence, \\ Reconstruction, and Reconciliation
}

\section{NOVEMBER 20-23, 2014 - JW MARRIOTT INDIANAPOLIS HOTEL}

\section{DEADLINE FOR \\ PROPOSAL SUBMISSION: \\ March 15, 2014 \\ PROGRAM CHAIRS \\ Odile Cazenave, Boston University \\ Clifton Crais, Emory University}

\begin{abstract}
About the Meeting
We are soliciting proposals for papers, panels, and roundtables. Presentations may focus on the theme of "Rethinking Violence, Reconstruction, and Reconciliation" or on broader social science, humanities, and applied themes relating to Africa. We strongly encourage the submission of formed panels. You can find more information on the theme and the call for proposals at the ASA website, www.africanstudies.org.
\end{abstract}

\section{How to Submit a Proposal} Instructions for submitting proposals can be found online on the ASA website, www.africanstudies.org.

\begin{abstract}
About the
African Studies Association

Established in 1957, the African Studies

Association is the largest organization in the world devoted to enhancing the exchange of information about Africa. Our members include scholars, students, teachers, activists, development professionals, policy makers, donors and many others. We encourage interdisciplinary interactions with Africa. We provide access to pathbreaking research and key debates in African studies. We bring together people with scholarly and other interests in Africa through our annual meeting and seek to broaden professional opportunities in the field of African studies. The organization publishes two leading interdisciplinary journals on Africa, African Studies Review and History in Africa and promotes an informed understanding of Africa to the public and in educational institutions as well as to businesses, media, and other communities that have interests in Africa.
\end{abstract}

For general questions regarding the meeting and/or registration please contact members@africanstudies.org. For questions regarding the submission process, guidelines, or program theme please contact asameeting2014@gmail.com.

\section{We welcome your participation in this exciting conference and in the ASA!}

Follow the ASA on Twitter, @ASANewsOnline, for updates on the Annual Meeting 


\section{CAMBRIDGE}

\section{Outstanding Titles from Cambridge University Press}

E-books Available for most titles!
Ancient Persia

A Concise History of the Achaemenid Empire, 550-330 BCE

\section{Matt Waters}

585.00: HB: 978-1-107-00960-8 S28.99: PB: 978-0-521-25369-7: $272 \mathrm{pp}$.

\section{Architecture,} Astronomy and Sacred Landscape in Ancient Egypt Giulio Magli \$99.00: HB: 978-1-107-03208-8: $284 \mathrm{pp}$.

\section{Open Standards} and the

Digital Age

History, Ideology, and Networks

Andrew L. Russell

Cambridge Studies in the Emergence of Global Enterprise

S99.00: HB: 978-1-107-03919-3 S29.99: PB: 978-1-107-61204-4: $320 \mathrm{pp}$.

The Body in History

Europe from the Palaeolithic to the Future Edited by John Robb and Oliver J. T. Harris \$115.00: HB: 978-0-521-19528-7: $287 \mathrm{pp}$.

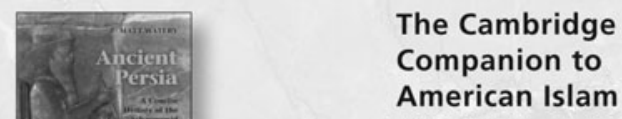

Edited by

Juliane Hammer and Omid Safi

Cambridge Companions to Religion

S95.00: HB: 978-1-107-00241-8 S32.99: PB: 978-0-521-17552-4: $386 \mathrm{pp}$.

\section{The First} Knowledge

\section{Economy}

Human Capital and the European Economy, 1750-1850

Margaret C. Jacob S85.00: HB: 978-1-107-04401-2 S29.99: PB: 978-1-107-61983-8: $265 \mathrm{pp}$.

\section{The Sugar}

Plantation

in India and Indonesia Industrial Production, 1770-2010

Ulbe Bosma

Studies in Comparative World History

S99.00: HB: 978-1-107-03969-8: $332 \mathrm{pp}$.

Prices subject to change

www.cambridge.org

@cambUP_History

@CUP_Anthro_Soc 


\section{CAMBridge JDURNALS}

\section{Central European History}

Published for the Conference Group for Central European History of the American Historical Association

\section{Editor-in-Chief}

Kenneth Ledford, Case Western Reserve University, USA

Associate Editor (Book Reviews)

Catherine Epstein, Amherst College, USA

Central European History offers articles, review essays, and book reviews that range widely through the history of Germany, Austria, and other German-speaking regions of Central Europe from the medieval era to the present. All topics and approaches to history are welcome, whether cultural, social, political, diplomatic, intellectual, economic, and military history, as well as historiography and methodology. Contributions that treat new fields, such as post-1945 and post-1989 history, maturing fields such as gender history, and less-represented fields such as medieval history and the history of the Habsburg lands are especially desired. The journal thus aims to be the primary venue for scholarly exchange and debate among scholars of the history of Central Europe.

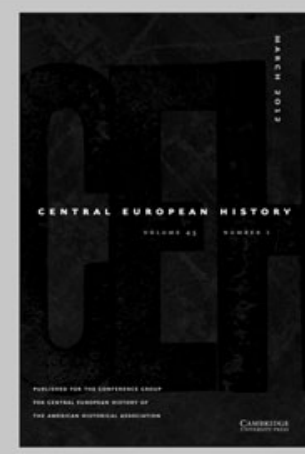

Central European History is available online at: http://journals.cambridge.org/ccc

To subscribe contact Customer Services

in Cambridge:

Phone $+44(0) 1223326070$

$\mathrm{Fax}+44(0) 1223325150$

Email journals@cambridge.org

in New York:

Phone +1 (845) 3537500

Fax +1 (845) 3534141

Email

subscriptions_newyork@cambridge.org

\section{Free email alerts}

Keep up-to-date with new material - sign up at

journals.cambridge.org/register

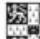
UNIVERSITY PRESS 


\section{COMPARATIVE STUDIES IN SOCIETY AND HISTORY \\ ISSN 0010-4175 \\ Founded by Sylvia L. Thrupp}

Comparative Studies in Society and History is a forum for new research and interpretation concerning problems of recurrent patterning and change in human societies through time and in the contemporary world. It sets up a working alliance among specialists in all branches of the social sciences and humanities. Review articles and discussions bring readers into touch with current findings and issues.

\section{NOTES FOR CONTRIBUTORS}

CSSH welcomes submissions. Essays should be written in such a way that complex issues are made intelligible and appealing to erudite readers who are not specialists in the subject under investigation. The editors prefer essays that are concise and will not accept for review essays over 14,000 words, including notes and references. Authors are also required to attach an abstract of no more than 250 words in length, including a concise description of their hypothesis, methodology, key sources, and conclusions. Please include with your submission your full contact information, including your email address.

The editors ask that submissions be presented in a manner that facilitates the work of reviewing and editing. Please submit a digital version of your work by email attachment to: hist-cssh@umich.edu, or on a CD. No printed copies are required. The journal works in Microsoft Word. The journal uses Windowsbased PCs exclusively. The work should be formatted in 12-point type and double-spaced throughout, including quotations, notes, and bibliography. Please allow generous margins of an inch or more for editorial corrections. Authors of essays accepted for publication must secure and submit permissions to reproduce photographs or other illustrations and tables.

Digital media or hard copies of correspondence may be sent to:

David Akin, Managing Editor

Comparative Studies in Society and History

University of Michigan

1007 East Huron

Ann Arbor, MI 48109-1690

USA

Please do not post materials to us by a means that requires a signature for delivery. 


\section{COMPARATIVE STUDIES IN SOCIETY AND HISTORY}

Editorial Foreword

255-258

Shared Pathways in U.S.-Soviet Relations

David E. Greenstein Assembling Fordizm: The Production of Automobiles, Americans, and Bolsheviks in Detroit and Early Soviet Russia

Oscar SAnchez-Sibony Capitalism's Fellow Traveler:

The Soviet Union, Bretton Woods, and the Cold War, 1944-1958

Scholars, Subjects, and the State

GREGGOR MatTson Nation-State Science: Lappology and Sweden's Ethnoracial Purity

RICHARD J. REID Ghosts in the Academy: Historians and Historical Consciousness in the Making of Modern Uganda $351-380$ Josh Berson The Dialectal Tribe and the Doctrine of Continuity $381-418$

(Moral) Order in the Court

PAOLO SARTORI Constructing Colonial Legality in

Russian Central Asia: On Guardianship

YÜKSEL SEZGIN AND MiRJAM KÜNKLER Regulation of

"Religion" and the "Religious": The Politics of

Judicialization and Bureaucratization in India and Indonesia

PNINA Werbner "The Duty to Act Fairly": Ethics, Legal

Anthropology, and Labor Justice in the Manual Workers

Union of Botswana

Melissa Demian On the Repugnance of Customary Law

508-536

\section{CSSH Discussion}

